\title{
Logit Analysis of the Relationship between Interest Rate Ceiling and Micro Lending Market in Kenya
}

\author{
Onyango Barnabas Ochieng ${ }^{1} \&$ Alphonce Juma Odondo ${ }^{2}$ \\ ${ }^{1}$ School of Business and Economics, Maseno University, Kenya \\ ${ }^{2}$ School of Business and Economics, Tom Mboya University College, Maseno University, Kenya \\ Correspondence: Alphonce Juma Odondo, Tom Mboya University College, a constituent college of Maseno \\ University, Kenya. Tel: 0592-0090/074-640-1703/074-640-1706. E-mail: alphonceodondo@gmail.com
}

Received: May 15, 2018

doi:10.5539/ijef.v10n8p105
Accepted: July 1, 2018

Online Published: July 10, 2018

URL: https://doi.org/10.5539/ijef.v10n8p105

\begin{abstract}
Interest rate ceilings have been declining over the past decades as most developing countries continue liberalizing their financial policies. Prior to 2015, Kenya's banking sector was vibrant and highly profitable. The sector loan book grew at an impressive compound annual rate of $16 \%$ in 2011 to 35\% in 2015. However, after interest rate cap in 2016, there has been a general slowdown in micro lending and rise in non-performing loans. Some studies argue that the ceiling protects consumers from exploitation and guarantees access to credit while others observe the contrary. This study sought to establish the relationship between interest rate ceiling and micro lending in Kenya. It was anchored on financial accelerator effect theory and the theory of financial repression. The study relied on secondary data from Banks and Micro Entrepreneurs. Logit models were estimated to establish the relevant relationships. It was established that interest rate ceiling had significant negative association with credit supply and default rate. However, it had a significant positive association with cost of Credit. Both Nagelkerke's $\mathrm{R}^{2}$ and Cox and Snell's showed that the estimated model fitted well. The Wald criterion demonstrated that credit supply, costs of credit and default rate were significantly different from zero. Thus, the independent variables were significantly affected by interest rate ceiling. It is recommended that banks pursuing policy of increasing credit supply and reducing cost of credit should advocate for the repeal of interest rate ceiling while those interested in reducing default rate should advocate for its retention.
\end{abstract}

Keywords: interest rate, ceiling, micro lending, market, Kenya

\section{Introduction}

According to Thomas, Edelman, and Crook, (2002), the phenomenon of borrowing and lending has a long history associated with human behavior. This is corroborated by the observation of Dankwa and Badu (2013) that modern banking started in England and it grew out of the custom of goldsmiths who took in their customers' gold and silver for safe keeping. They then discovered that they could lend such precious metals out and keeping just a certain customer proportion as reserves.

In order to start a business, entrepreneurs need startup capital which partly comes from loans. The act of lending money in small amounts to individuals with the aim of starting or running a small business is termed as micro lending. The history of micro lending according to Childers (2015) began in Bangladesh and has henceforth continued in human life. For instance, Yunus 1974 issued the first microloans to basket weavers in an economically depressed area of Bangladesh, a scenario that eventually led to the evolution of the Grameen Bank.

Yunus and Jolis (1999), explained that the said weavers were unable to purchase materials for the construction of their goods due to monetary constraints and were therefore, forced to rely on loans from local lenders who charged interest rates that left meager profits for the basket weavers after the loan repayment. The issue of meager profits could be addressed if the basket weavers were able to obtain just one loan with favorable terms that would allow them to retain their profits and reinvest them in their business. However, the disjoint here is that, banks are keener on risks associated with lending. Avevor (2016) indicated that it is because of the perception of higher risk, informational barriers, and the higher costs of intermediation for smaller firms that micro enterprises fail to obtain long-term finance in the form of debt and equity. Nevertheless, when lenders know more about borrowers, their credit history, or other lenders to the firm and get collaterals, they are more willing to extend 
credit (Djankova, McLeish, \& Shleifer, 2007).

For financial institutions to extend credit facilities to micro enterprises and remain sustained and active in the market, Khandare and Alshebami (2015) suggested that it is mandatory for them to cover their costs and expenses incurred when carrying out such activities. Various costs such as cost of borrowing, cost of operation, inflation cost, cost of default loans and other costs of delinquencies with the profit margin have to be recovered by MFIs so that they can continue working smoothly and effectively in the market otherwise they have to depend largely on the government subsidies or the donors grants which do not last forever. Mbengue (2013), noted that over the past two decades, institutions that extend microloans to low-income borrowers in developing and transition economies have focused increasingly on making their operations financially sustainable by charging interest rates that are high enough to cover all their costs. This is in tandem with Reille and Helms (2004), who asserted that Microcredit costs are high, but not because lending to poor clientele carries inherently higher risk but because of the greater delivery costs of tiny transactions that require face-to-face interaction and because MFIs use personal contact as a substitute for formal collateral or computerized credit scoring.

The high interest rates charged by many microfinance institutions (MFIs) have attracted the attention of policy makers throughout the world (Reille \& Helms, 2004). The main issue of concern in this case is why financial institutions, whose core business is to serve the disadvantaged poor people, charge them unreasonably high interest rates? This dilemma led more than 40 countries in the world to impose ceilings on the interest rate demanded by MFIs as a way to protect micro entrepreneurs from this practice (Mbengue, 2013; CGAP, 2004). In addition, such ceilings are the results of governments facing cultural or political pressure to keep interest rates low. Imposing interest rate ceiling on lending makes it very difficult for the MFIs to recover their costs, consequently curtailing their lending to micro enterprises (Mbengue, 2013; Miller, 2013).

According to Mohane, Gerhard, and William (2002), Government's participation in the operations of the market tend to hamper the free interaction of supply and demand forces that determine equilibrium quantity and price. Artificial cap on interest rates distorts allocation of resources particularly when the equilibrium price is higher than the capped rate. Reille and Helms (2004); Miller (2013), noted that ceilings that are set too low and those that are set too high are both problematic especially in cases where they do not cover fees and commissions. In situations where the scope of ceiling is not clear, financial institutions may give the impression of compliance with the ceiling but charge fees and commissions that are not considered part of the cost of the loan. In South Africa, some financial institutions evaded caps by charging credit life insurance and other services, which reduced the transparency of the total cost of credit and in Armenia, the lack of clarity on how to calculate the interest rate led banks and microfinance institutions to impose fees and commissions, thus avoiding the ceiling and reducing the transparency for consumers (Maimbo \& Gallegos, 2014). Mohane et al. (2002), argue that the consequence is people who want finance, but due to their circumstances do not qualify at the ceiling interest rate are denied access. Interest rate ceilings make it difficult or impossible for formal and semi-formal micro lenders to cover their costs, driving them out of the market (Reille \& Helms, 2004). In Nicaragua for instance, microfinance institutions reduced lending thus, subjecting them to high business risks and operational costs which eventually led to their relocation from the rural areas.

Empirical studies indicate that interest rates caps have been declining over the past several years as most of the developing economies continue liberalizing their financial policies. The interventions are meant to increase accessibility of financial markets with the aim of stimulating economic growth through enhanced productivity and poverty reduction (Bekaert, Harvey, \& Lundblad, 2001). In United States for instance, Laeven (2003) revealed that financial liberalization measure such as the removal of interest caps had positive effect on small enterprises' access to finance. However, the global financial crisis of 2008 that affected several nations reopened the debate on interest rate controls as a tool for consumer protection. Countries like El Salvador, the Kyrgyz Republic, and Zambia responded by introducing fresh interest rate caps on loans. Japan among other economies responded by imposing more restraing caps (Maimbo \& Gallegos, 2014).

Other scholars argue that the caps are generally justified for consumer protection and a sure way of guaranteeing access to credit at reasonable interest rates. They can also help protect the public interest by ensuring a fair and reasonable interest rate on loans. On the other hand, interest rate ceilings may also be a good way to limit access to credit to some impaired and low-income consumers, because they help avoid social harm (Reille \& Helms, 2004). Studies show that interest ceilings on loans were successful in the Republic of Korea for the period 1956-1994 and that financial liberalization did not significantly help increase financial depth (Maimbo \& Gallegos, 2014).

Banking industry in Kenya is currently going through a development process that the majority of advanced 
economies have already been through, having introduced interest rate ceiling in August, 2016. The sector framework as at $31^{\text {st }}$ December, 2015 comprised of 54 financial institutions, 42 of which were Banking institutions, and 12 deposit taking micro finance institutions (DTMs) with the Central Bank of Kenya (CBK) as the regulatory body (Banking Survey, 2015), 1 mortgage finance company, 2 credit reference bureaus, 3 representative offices and 124 foreign exchange bureaus (CBK, 2016).

Before the introduction of interest ceiling, Kenya's banking sector was observed as a vibrant, highly profitable sector, with the overall average capital adequacy ratio of $19 \%$ against a statutory minimum of $14.5 \%$ and a liquidity ratio of $38.3 \%$ as at $30^{\text {th }}$ December 2015 (CBK, 2016). The industry's Return on assets averaged at $20 \%$ while sector loan book grew at an impressive compound annual rate of $16 \%$ in 2011 to $35 \%$ in 2015 (AIB Capital (2016).

However, following the introduction of the interest rate cap in August 2016, there has been a general slowdown in micro lending, for instance in January 2016, it grew at 16.8\%, 5.4\% in August 2016 and a paltry $4.3 \%$ in December 2016. Furthermore, the banks resorted to staff reduction and closure of some branches (Olaka, 2017). Non-performing loans also increased across the sector from an industry average of 5.2\% before 2015 to an average of $7.9 \%$ as at September 2016 (AIB Capital, 2016).

From the foregoing literature, it is clear that studies have been done on interest rate ceiling and its impact on various aspects of micro lending market such as credit supply, cost of loan and default rate. However, they generated mixed results. While some argue that ceiling is an inefficient tool for lowering interest rates and limits access to credit, reduces transparency and promotes lending to only credit worthy individuals, others are of the opinion that it protects the consumers from usury and exploitation by guaranteeing access to credit at reasonable interest rates. Furthermore, the studies largely focused on developed countries whose GDP were higher than those of developing economies. Therefore, results from such economies should be treated with a lot of caution in relation to developing economies like Kenyan. Consequently, a country specific study is inevitable for clear policy formulation. It is on this basis that the study sought to establish the relationship between interest rate ceiling and micro lending market in Kenya. The guiding hypotheses were:

$\mathrm{H}_{01}$ : There is no relationship between Interest rate ceiling and credit supply to micro enterprises in Kenya.

$\mathrm{H}_{02}$ : There is no relationship between Interest rate ceiling and cost of credit to micro enterprises in Kenya

$\mathrm{H}_{03}$ : There is no relationship between Interest rate ceiling and default rate by the micro enterprises in Kenya

\subsection{Theoretical Framework}

The theoretical foundation of this study was laid on the works of Bernanke, Gertler, and Gilchrist (1996); McKinnon (1973) and Shaw (1973). Bernanke et al. (1996) developed a financial accelerator effect model in which there is a two-way link between the borrowing costs of firms and their net worth. In this model, entrepreneurs who borrow funds to undertake investment projects, face an external finance premium that rises when their leverage increases.

The financial accelerator results from changes in credit market conditions due to various economic shocks, which affect the intrinsic costs of borrowing and lending, associated with asymmetric information. Miller (2013) explains that asymmetric information where financial institutions are able to exploit information before their clients may lead to market imperfections resulting to adverse selection and moral hazard problems, hence invalidating the standard competitive market results. The framework illustrates developments in the credit market that amplifies and propagates shocks to the macro economy.

The key mechanism involves the link between external finance premium and the opportunity cost of funds internal to the firm as well as the net worth of potential borrowers. According to Almeida, Campello, and Liu (2006), the key idea behind the financial accelerator is the notion that shocks to the net worth of firms and households have a procyclical effect. With credit-market frictions present, and with the total amount of financing required held constant, standard models of lending with asymmetric information imply that the external finance premium depends inversely on borrowers' net worth (Bernanke et al., 1996). Miller (2013) argues that MFIs face difficulties in measuring the borrower's creditworthiness when making credit scoring decisions thus, raising two fundamental issues: Clients that have lower risk are adversely selected and are likely to receive some form of credit while those that remain will either be of high risk or low risk but unable to prove. MFIs being unable to differentiate will charge an aggregated rate which is attractive to the high risk client raising the probability of default. On the other hand, clients borrowing at a higher rate might be required to make riskier investments in order to cover their borrowing costs again leading to high probability of default.

Literature indicates that group lending methodology manages adverse selection risk by using social capital and 
risk understanding within a community to price risk. The problem is that interest rate ceilings are common at the lower end of the market where financial institutions use the information asymmetry to justify high lending rates. Practically in normal financial markets, larger commercial banks grant large credit at lower interest rates while MFIs give small amounts to a higher interest rate as illustrated in Figure 1.

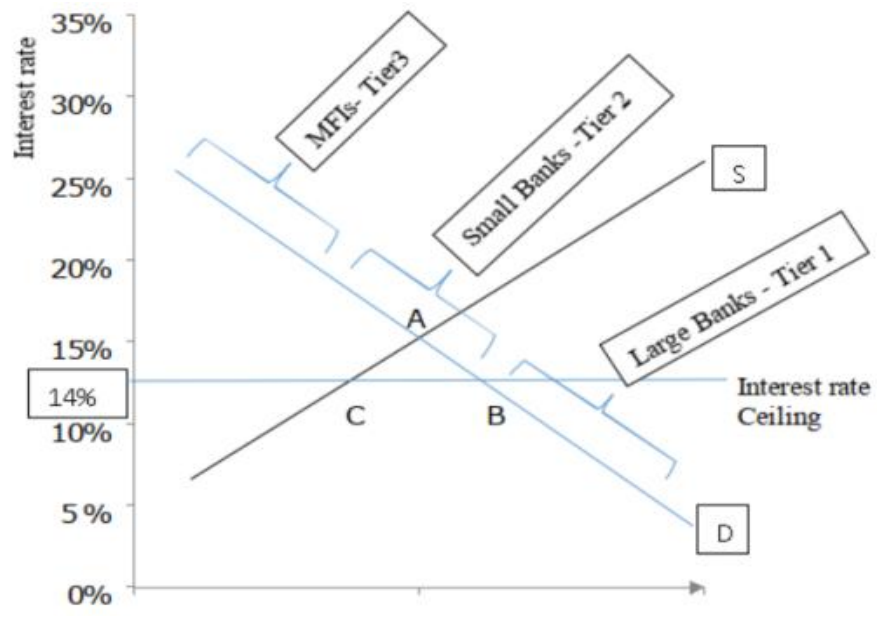

Credit Supply

Figure 1. Imposition of an interest rate ceiling on demand schedule for credit.

Source: Adapted from Miller (2013); Mohane et al. (2002).

The Figure shows that when government imposes a ceiling on interest rate at $4 \%$ above CBR, it translates to $14 \%$. Lenders are therefore, forced to shift the supply curve outward to the right and increase access to credit bringing down lending rates e.g. from equilibrium A to a new equilibrium B. This however, assumes the risk and cost associated with micro lending. The information depicts how the banks and MFIs operating under asymmetric information would react. When ceiling is imposed, adverse selection problem is magnified and MFIs tend to lock out willing borrowers with unidentifiable creditworthiness. As such, MFIs can only intensify credit scoring processes to weed out bad borrowers- meaning increased overhead costs, increase lending- hence lending out to bad clients and pushing up non-performing loans. All these options will increase costs and force the supply curve back to the left, reducing quantity of credit supplied, refuse credit to other clients and the market moves to point $C$ (Khandare \& Alshebami, 2015).

The underlying assumptions of this theory are that the less resources the borrower contributes to the project, the more his interests will diverge from the interests of the supplier of external funds and the vice versa. On the other hand, in cases where the borrowers have more information about projects characteristics or where they have the ability to take unobserved actions that can affect investment return, a greater incompatibility of interests between borrowers and lenders increases agency costs. The types of agency costs depend on the way the information asymmetry in the credit market is modeled (Coric, 2011).

Another theory that relates to this study is the theory of financial repression. Financial repression is a deliberate and calculated distortion of financial prices by regulatory authorities in an economy (i.e. McKinnon-Shaw hypothesis), which refers to the policies that place interest rate ceiling on deposits and lending. The theory elucidates how financial repression can distort and greatly interfere with the micro lending market resulting into adverse effect on economic growth due to reduced credit supply (McKinnon, 1973; Shaw, 1973). This supports the argument of Fry (1997), Demetriades and Luintel (1997) who asserted that the use of interest rate ceilings, distorts the economy and inhibits financial deepening by depressing real rates of interest.

Even though McKinnon's model emphasizes on a direct relationship between the demand for credit and physical investment in a business, Shaw model used the debt-intermediation view to show the whole process of financial intermediation, departing from the deposit accumulation and culminating in the expansion of the lending capacity of the banking institutions (Fernandez, 2011). McKinnon-Shaw framework argues that in order for an economy to experience economic growth via greater efficiency in capital accumulation and allocation, interest rate ceilings, credit control and other restrictive financial legislations should be removed (Orji, Ogbuabor, \& Onyinye, 2015). The essential common elements of the McKinnon and Shaw approaches can be summarized as illustrated in the Figure 2. 


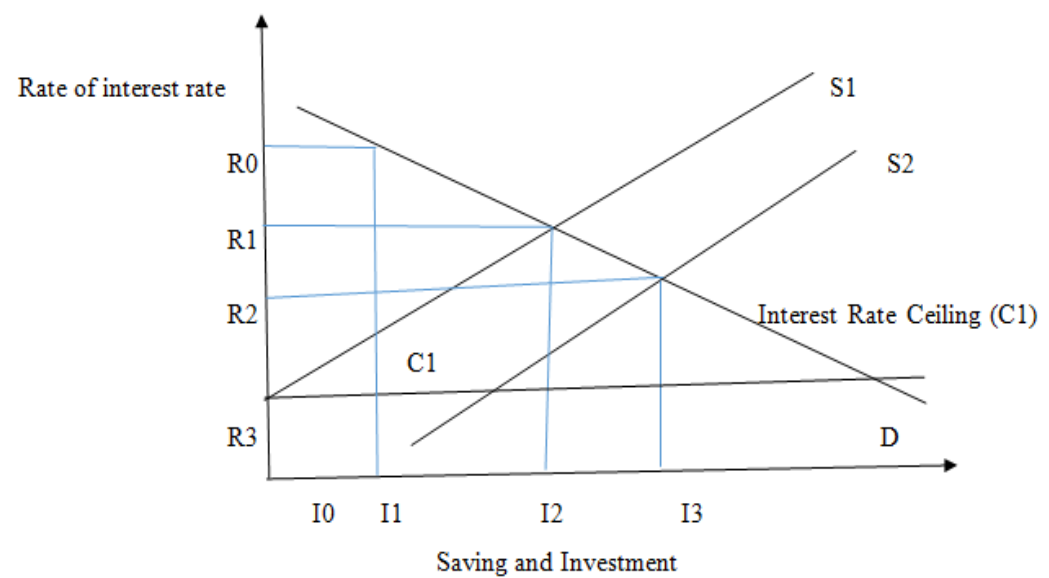

Figure 2. Model for interest rate ceiling, savings and investment

Source: Adapted from Orji, Ogbuabor, and Onyinye (2015).

Figure 2 Shows that the supply of credit (S1) is a positive function of the interest rate. At the interest rate (R1), the supply of credits appears as the binding constraint in the credit market and the investment is limited to available amount of saving (I2). If the interest rate ceiling is applied (C1), the borrower will pay the ceiling rate (R3) resulting into high spread of financial intermediation (R0 - R3). This evidences the inefficiency of a banking system which operates with a deposit rate ceiling and shows that a set of government regulations, laws, and other non-market restrictions may prevent the financial intermediaries of an economy from functioning at their full capacity (Orji et al., 2015). From the foregoing illustration of the loanable funds theory and Bernanke et al. (1996) view, the lower the borrower's savings, the more his interests will diverge from the interests of the supplier of the external funds and if the interest is capped, the borrowers with less savings will eventually be locked out of credit supply.

\section{Research Methodology}

\subsection{Research Design}

The study adopted correlational research design. The design is suitable for studies that seek to establish relationships (Kothari, 2004). In this study, the design helped in the determination of association and the relationship between interest rate ceiling and performance indicators of the microenterprises in Kenya.

\subsection{Study Area}

This study was conducted in Migori county of Kenya. The Republic of Kenya has its geographic location in Eastern Africa with latitude of $1^{\circ} 00^{\prime} \mathrm{N}$ and a longitude of $38^{\circ} 00^{\prime} \mathrm{E}$. Being the Forty Seventh largest country in terms of land area, the latitude and longitude of Kenya covers an area of 582,650 sq km. Although the study was conducted in Migori county of Kenya, the interest rate ceiling was a national issue and the findings would be used to generalize on the situation in the entire country.

\subsection{Data Type, Sources and Collection Methods}

The study relied on monthly Secondary data sourced from Bank Supervision Reports, official websites of commercial banks and micro entrepreneurs. The data were on credit supply, cost of credit and default rate. The data covered December, 2014 to June, 2017 giving 31 observational points.

\subsection{Data Analysis}

Correlation analysis was used to determine the bivariate association between the explanatory variables and the interest rate ceiling. Logistic regression analysis was used to describe the relationship between interest rate ceiling and micro lending. The logit model was adopted from Magali (2013), and specified as shown in Equation 1.

$$
\text { Logit }(P)=\log \left[\frac{P_{i}}{1-P_{i}}\right]
$$

Where the term within the square bracket refers to the odds of an event occurring.

The model was re specified as: 


$$
\begin{gathered}
\log \left[\frac{P_{i}}{1-P_{i}}\right]=\operatorname{Logit}\left(P_{i}\right)=\beta_{0}+\beta_{1} X \\
\forall_{i}=1-3
\end{gathered}
$$

$1^{s t}{ }_{i}=$ Increased Credit supply or otherwise; $2^{\text {nd }}{ }_{i}=$ Decreased cost of credit or otherwise.

$3^{r d}{ }_{i}=$ Decreased default rate or otherwise.

\section{Results}

To achieve the study's objective, the data obtained was analyzed using correlation and logistic regression analysis and the results presented as below:

\subsection{Correlation Analysis}

Table 1 shows correlation matrix for the interest rate ceiling, credit supply, cost of credit and default rate. Interest rate ceiling had a significant negative correlation with credit supply $(\mathrm{r}=-.718, p=.000)$ and default rate $(r=-.795, \mathrm{p}=.000)$. This means that $71.8 \%$ and $79.5 \%$ reduction in credit supply and default rate respectively were associated with interest rate ceiling, suggesting that after the introduction of interest rate ceiling, MFI's experienced a reduction of $78.1 \%$ in the number of loans disbursed and $79.5 \%$ fall in the default rate. A reduction in the default rate is a great achievement for MFI's and Commercial Banks that have suffered losses due to high loans default rate. On the other hand, a significant positive association was established between interest rate ceiling and the cost of credit $(r=.642, p=.001)$. This implies that $64.2 \%$ variation in the cost of credit was associated with the interest rate ceiling.

Although the focus of the study was the association between the interest rate ceiling and the three explanatory variables, the study further revealed a significant negative association between the credit supply and cost of credit $(r=-.930, p=.001)$, a likely indication that $93 \%$ reduction in the credit supply could be associated with the cost of credit. Conversely a positive significant association was established between credit supply and default rate $(r=.656, p=.001)$. This shows that $65.6 \%$ increase in the default rate could be associated with the rise in credit supply.

\begin{tabular}{|c|c|c|c|c|c|}
\hline & & Interest Rate Ceiling & Credit Supply & Cost of Credit & Default Rate \\
\hline \multirow[t]{3}{*}{ Interest Rate Ceiling } & Pearson Correl & 1 & & & \\
\hline & Sig. (2-tailed) & & & & \\
\hline & $\mathrm{N}$ & 31 & & & \\
\hline \multirow[t]{3}{*}{ Credit Supply } & Pearson Correl & $-.718^{* *}$ & 1 & & \\
\hline & Sig. (2-tailed) & .000 & & & \\
\hline & $\mathrm{N}$ & 31 & 31 & & \\
\hline \multirow[t]{3}{*}{ Cost of Credit } & Pearson Correl & $.642^{* *}$ & $-.930^{* *}$ & 1 & \\
\hline & Sig. (2-tailed) & .000 & .000 & & \\
\hline & $\mathrm{N}$ & 31 & 31 & 31 & \\
\hline \multirow[t]{3}{*}{ Default Rate } & Pearson Correl & $-.795^{* *}$ & $.656^{* *}$ & $-.585^{* *}$ & 1 \\
\hline & Sig. (2-tailed) & .000 & .000 & .001 & \\
\hline & $\mathrm{N}$ & 31 & 31 & 31 & 31 \\
\hline
\end{tabular}

Table 1. Correlation matrix on the interest rate ceiling and dimensions of micro lending

**. Correlation is significant at the 0.01 level (2-tailed).

Source: Authors, 2017.

\subsection{Regression Analysis Results}

A binary logistic regression analysis was conducted to determine the effect of interest rate ceiling on the credit supply among the micro enterprises. The Secondary data collected was coded to give a binary data (Increased Credit Supply $=1$ or Otherwise $=0$ ). The results are captured in Table 3.

Table 3 shows the estimated Cox and Snell's $\mathrm{R}^{2}$ which generally imitate multiple $\mathrm{R}^{2}$ based on 'likelihood', but its maximum can be less than 1.0. The study revealed Cox and Snell's $\mathrm{R}^{2}$ of .42 , suggesting that $42 \%$ of variations in credit supply is explained by the interest rate ceiling. Nagelkerke's $\mathrm{R}^{2}$ was estimated at .577 , indicating a strong relationship between the interest rate ceiling and the credit supply. The overall fit of the model was assessed using the log likelihood statistics, a value that is multiplied by -2 to give $-2 \log$ likelihood (-2LL). Under this model, Table 4 shows -2LLstatistics of 23.434, which is a slight improvement from the constant only 
model where it was 15.989 (Table 2). This implies that fitting the model would be better than the constant only model.

Table 5, shows that $90 \%$ of the responses were correctly classified for increased credit supply and $81.8 \%$ for otherwise. Overall $87.1 \%$ were correctly classified. This is a considerable improvement on the $64.5 \%$ (Table 4) correct classification with the constant model, and shows that the model with predictors is a better model.

Table 2. Block 0: Binary logistic regression for Variables not in the equation for predicting likely effect on credit supply

\begin{tabular}{|c|c|c|c|c|c|}
\hline & & & Score & $\mathrm{df}$ & Sig. \\
\hline \multirow[t]{2}{*}{ Step 0} & Variables & Interest Rate Ceiling & 15.989 & 1 & .000 \\
\hline & Overall Statistics & & 15.989 & 1 & .000 \\
\hline
\end{tabular}

Source: Authors, 2017.

Table 3. Binary logistic regression results showing likely effect of ceiling on credit supply

\begin{tabular}{lccc}
\hline Step & -2 Log likelihood & Cox \& Snell R Square & Nagelkerke R Square \\
\hline 1 & 23.434 & .420 & .577 \\
\hline
\end{tabular}

a. Estimation terminated at iteration number 5 because parameter estimates changed by less than .001 .

Table 4. Block 0: Binary logistic regression results for classification and prediction of credit supply

\begin{tabular}{lllccc}
\hline & & \multicolumn{3}{c}{ Predicted } \\
\cline { 3 - 4 } & & & \multicolumn{2}{c}{ Credit Supply } & \\
\cline { 3 - 4 } & Observed & Otherwise & Increased Credit Supply & Percentage Correct \\
\hline Step 1 & Credit Supply & Otherwise & 0 & 11 & .0 \\
& & Increased Credit Supply & 0 & 20 & 100.0 \\
& Overall Percentage & & & & 64.5 \\
\hline
\end{tabular}

a. Constant is included in the model; b. The cut value is .500.

Table 5. Binary logistic regression results for classification and prediction of credit supply

\begin{tabular}{lllccc}
\hline & & \multicolumn{3}{c}{ Predicted } \\
\cline { 3 - 4 } & & & \multicolumn{2}{c}{ Credit Supply } \\
\cline { 3 - 5 } & Observed & Otherwise & Increased Credit Supply & Percentage Correct \\
\hline \multirow{2}{*}{ Step 1 } & Credit Supply & Otherwise & 9 & 2 & 81.8 \\
& & Increased Credit Supply & 2 & 18 & 90.0 \\
& & & & 87.1 \\
\hline
\end{tabular}

a. The cut value is .500

Table 6 show p-values below 0.05 , suggesting a significant relationship between the credit supply and interest rate ceiling. The Wald statistic $=11.743, d f=1, \mathrm{p}=0.001$, confirms the general null hypothesis that the "B" coefficients are significantly different from Zero. The Exp (B) column presents the extent to which raising the corresponding measure by one unit influences the odds ratio. $\operatorname{Exp}(B)=0.25<1$, implies that the probability of decrease in credit supply is higher than before the introduction of interest rate ceiling (i.e. the odds of decrease in credit supply was about $75 \%(=0.25 * 100-100)$ after ceiling.

Table 6. Binary logistic regression for effect of interest rate ceiling on credit supply

\begin{tabular}{llcccccccc}
\hline & & B & S.E. & Wald & df & Sig. & Exp(B) & \multicolumn{2}{c}{ 95\% C.I.for EXP(B) } \\
\cline { 5 - 10 } & & & & & & & & Lower & Upper \\
\hline Step & Interest Rate Ceiling & -3.701 & 1.080 & 11.743 & 1 & .001 & .025 & .003 & .205 \\
1 & Constant & 2.197 & .745 & 8.690 & 1 & .003 & 9.000 & & \\
\hline
\end{tabular}

a. Variable(s) entered on step 1: Interest rate Ceiling.

\subsubsection{Effect of Interest Rate Ceiling on the Cost of Credit to Micro Enterprises}

From Table 7, Cox and Snell's R-Square $=.344$, meaning this model indicates that $34.4 \%$ of variations in Cost of 
Credit is explained by the logistic model. Nagelkerke's $\mathrm{R}^{2}=.481$, indicating a relationship of $48.1 \%$ between the interest rate ceiling and the Cost of Credit. The overall fit of the model was given by $-2 \mathrm{LL}=25.894$, which is an improvement from the constant only model $=12.778$ (Table 8 ). Table 9 , shows that $80 \%$ were correctly classified for decreased cost of credit and $85.7 \%$ for otherwise. Overall $83.9 \%$ were correctly classified which shows an improvement on the $67.7 \%$ (Table 10) correct classification with the constant only model.

Table 7. Binary logistic regression results showing likely effect of ceiling on cost of credit

\begin{tabular}{lccc}
\hline Step & -2 Log likelihood & Cox \& Snell R Square & Nagelkerke R Square \\
\hline 1 & 25.894 & .344 & .481 \\
\hline
\end{tabular}

a. Estimation terminated at iteration number 5 because parameter estimates changed by less than .001 .

Table 8. Block 0: Binary logistic regression for variables not in the equation for predicting likely effect on cost of credit

\begin{tabular}{|c|c|c|c|c|c|}
\hline & & & Score & df & Sig. \\
\hline \multirow[t]{2}{*}{ Step 0} & Variables & Interest Rate Ceiling & 12.778 & 1 & .000 \\
\hline & Overall S & & 12.778 & 1 & .000 \\
\hline
\end{tabular}

Source: Authors, 2017.

Table 9. Binary logistic regression results for classification and prediction of cost of credit

\begin{tabular}{lllccr}
\hline & & \multicolumn{3}{c}{ Predicted } \\
\cline { 3 - 4 } & & & \multicolumn{2}{c}{ Cost of Credit } & \\
\cline { 3 - 4 } & Observed & Otherwise & Decreased Cost of credit & Percentage Correct \\
\hline Step 1 & Credit Supply & Otherwise & 18 & 3 & 85.7 \\
& & Decreased Cost of Credit & 2 & 8 & 80.0 \\
& & & & 83.9 \\
\hline
\end{tabular}

a. The cut value is .500

Table10. Block 0: Binary logistic regression results showing cost of credit was correctly classified and predicted

\begin{tabular}{lllccc}
\hline & & \multicolumn{3}{c}{ Predicted } \\
\cline { 3 - 4 } & & & \multicolumn{2}{c}{ Cost of Credit } & \\
\cline { 3 - 4 } & Observed & Otherwise & Decreased Cost of credit & Percentage Correct \\
\hline Step 1 & Credit Supply & Otherwise & 21 & 0 & 100.0 \\
& & Decreased Cost of Credit & 10 & 0 & .0 \\
& & & & 67.7 \\
\hline
\end{tabular}

a. The cut value is .500 .

Table 11 shows a strong relationship between the cost of credit and interest rate ceiling at $\mathrm{P}<0.05$; Wald $=9.962$, $d f=1, \mathrm{p}=0.002$. The $\operatorname{Exp}(\mathrm{B})=24.000$ suggests that the probability of increase in cost of credit is 24 times more likely to be higher than the original value with the introduction of interest rate ceiling

Table 11. Binary logistic regression for effect of interest rate ceiling on cost of credit

\begin{tabular}{llccccccccc}
\hline & & B & S.E. & Wald & df & Sig. & \multicolumn{2}{c}{ Exp(B) } & 95\% C.I. for EXP(B) \\
\cline { 3 - 8 } & & & & & & & Lower & Upper \\
\hline Step & Interest rate Ceiling & 3.178 & 1.007 & 9.962 & 1 & .002 & 24.000 & 3.335 \\
1 & Constant & -2.197 & .745 & 8.690 & 1 & .003 & .111 & .205 \\
\hline
\end{tabular}

a. Variable(s) entered on step 1: Interest rate Ceiling.

\subsubsection{Effect of Interest Rate Ceiling on the Default Rate by the Micro Enterprises}

Table 12 indicates that $-2 \mathrm{LL}=19.705$ which is a slight improvement from the constant only model where it was $=19.581$ (Table 13). Cox \& Snell $\mathrm{R}^{2}=.503$ while Nagelkerke's $\mathrm{R}^{2}=.683$, suggesting adequate descriptive goodness of fit test for the model. Table 14 shows that $94.7 \%$ of the cases were correctly classified for decrease 
in default rate and $83.3 \%$ for otherwise. Overall $90.3 \%$ were correctly classified. This is a good improvement on the $61.3 \%$ (Table15) correct classification with the constant model.

Table 12. Binary logistic regression results showing likely effect of ceiling on Default rate

\begin{tabular}{lccc}
\hline Step & -2 Log likelihood & Cox \& Snell R Square & Nagelkerke R Square \\
\hline 1 & 19.705 & .503 & .683 \\
\hline
\end{tabular}

a. Estimation terminated at iteration number 5 because parameter estimates changed by less than .001 .

Table 13. Block 0: Binary logistic regression for variables not in the equation for predicting likely effect on cost of credit

\begin{tabular}{|c|c|c|c|c|c|}
\hline & & & Score & $\mathrm{df}$ & Sig. \\
\hline \multirow[t]{2}{*}{ Step 0} & Variables & Interest Rate Ceiling & 19.581 & 1 & .000 \\
\hline & Overall St & & 19.581 & 1 & .000 \\
\hline
\end{tabular}

Source: Authors, 2017.

Table 14. Binary logistic regression results showing correct classification and prediction of default rate

\begin{tabular}{lllccr}
\hline & & \multicolumn{3}{c}{ Predicted } \\
\cline { 3 - 4 } & & & \multicolumn{2}{c}{ Default Rate } \\
\cline { 3 - 4 } & Observed & Otherwise & Decreased Default Rate & Percentage Correct \\
\hline \multirow{2}{*}{ Step 1 } & Default Rate & Otherwise & 10 & 2 & 83.3 \\
& & Decrease in Default Rate & 1 & 18 & 94.7 \\
& & & & 90.3 \\
\hline
\end{tabular}

a. The cut value is .500 .

Table 15. Block 0: Binary logistic regression results showing default rate was correctly classified and predicted

\begin{tabular}{lllccc}
\hline & & \multicolumn{3}{c}{ Predicted } \\
\cline { 3 - 4 } & & & \multicolumn{2}{c}{ Default Rate } & Percentage Correct \\
\cline { 3 - 5 } & Observed & Otherwise & Decreased Default Rate & 0 \\
Step 1 & Default Rate & Otherwise & 0 & 12 & 100 \\
& & Decrease in Default Rate & 0 & 19 & 61.3 \\
\hline
\end{tabular}

a. The cut value is .500 .

From Table 16 shows a strong relationship between the default rate and interest rate ceiling at $\mathrm{p}<.05$, Wald $=$ $12.231, d f=1, \mathrm{p}=.000$. The $\operatorname{Exp}(\mathrm{B})=.011$, implies that the probability of decrease in default rate with the introduction of interest rate ceiling is high. The odds of decrease is .011 times which is about $89 \%(=0.11 * 100-$ 100).

Table 16. Binary logistic regression results showing likely effect of ceiling on default rate

\begin{tabular}{llcccccccc}
\hline & B & S.E. & Wald & df & Sig. & Exp(B) & \multicolumn{2}{c}{$95 \%$ C.I. for EXP(B) } \\
\cline { 4 - 10 } & & & & & & & & Lower & Upper \\
\hline Step1 $^{\mathrm{a}}$ & Interest rate Ceiling & -4.500 & 1.287 & 12.231 & 1 & .000 & .011 & .001 & .138 \\
& Constant & 2.197 & .745 & 8.690 & 1 & .003 & 9.000 & & \\
\hline
\end{tabular}

a. Variable(s) entered on step 1: Interest rate Ceiling.

\section{Discussion}

The study found that interest rate ceiling is a significant determinant of credit supply, cost of credit and default rate of micro enterprises. It follows therefore, that with the interest rate ceiling and intense competition as well as globalization in the financial sector, MFIs and Banks should develop loan products that are more customer-oriented in order to be competitive in the dynamic micro lending market. The results corroborate the assertion of Staten (2008), that interest rate ceilings make small consumer loans from financial institutions impractical, pushing the underlying loan demand for small loans toward brokers and less reputable financiers 
(loan sharks) due to increased cost.

The finding that Interest rate ceiling affects micro lending market by reducing credit supply to micro enterprises was in tandem with Fry (1997), Demetriades and Luintel (1997), McKinnon (1973) and Shaw (1973), who stated that financial repression can distort and greatly interfere with the micro lending market resulting into adverse effect on economic growth due to reduced credit supply. Bernanke et al. (1996) stated that the less the savings owned by borrowers, the higher will be the divergence from the interests of the supplier of the external funds, and if the interest is capped, the borrowers with low savings will eventually be locked out of credit supply.

Chari, Shourideh, and Jones (2010) and Kurlat (2010), explained that informational frictions affect the availability of loans. When interest rates are capped at a rate lower than the equilibrium rate, borrowers who are not credit worthy drop out of the market due to adverse selection, reducing the credit supply. Heng (2015), while studying interest rate caps on financial stability and inclusion in Bolivia, concluded that interest rate cap had a significant effect on financial inclusion, especially for micro entrepreneurs, as microfinance institutions reduced the number of loans to micro borrowers.

From the results, interest rate ceiling affects micro lending market by increasing cost of credit to micro enterprises. This is supported by Maimbo and Gallegos (2014), who observed that in South Africa, MFIs evaded caps by charging credit life insurance and other services, which reduced the transparency of the total cost of credit. They further stated that in Armenia, lack of clarity on how to calculate the interest rate led MFIs to impose fees and commissions not defined by the ceiling laws. Reille and Helms (2004); Miller (2013), added that ceilings that are set too low and those that are set too high are both problematic especially in cases where they do not cover fees and commissions. Where the scope of ceiling is not clear, MFIs may give the impression of compliance with the ceiling but charge fees and commissions that are not considered part of the cost of the loan.

The revelation that interest rate ceiling reduced default rate by micro enterprises confirms findings by Rossouw (2008) that limiting fees impacted on the consumer's repayments on a micro loan thus, reducing default rate. Similar findings can be deduced from Kariuki and Ngahu (2016) who focused on the effect of interest rates on loan performance of microfinance institutions in Naivasha, region of Kenya and found that microfinance institutions faced high defaults on loans advanced due to high interest rates charged. In this study therefore, although interest rate ceiling is a relatively new concept in Kenya, the results are largely consistent with other related studies.

\section{Conclusions and Recommendations}

\subsection{Conclusions}

The results show that a significant proportion of reduction in credit supply was associated with interest rate ceiling, suggesting that interest rate ceiling implemented in Kenya in the year 2016 discourages provision of micro credit due to the difficulty of recovering variable costs associated with such lending. When interest ceiling terms are not properly defined, MFIs may be forced to create additional and more stringent terms in effort to recover administrative costs, this not only reduces transparency about the borrowers true cost but also camouflages the actual interest rates charged by MFIs. Lending practices without prudent regard for repayment capacity of micro enterprises, deceptive terms, and unlawful collection techniques causes more damage to microenterprises than do high interest rates.

Interest rate ceilings do not necessarily protect the micro lenders as it may be intended but can also hurt them by reducing their access to financial services. Even if such ceilings are intended to reduce usury and exorbitant lending by MFIs who charge very high interest rates, they are very difficult to enforce properly. However, this doesn't negate the critical need by the government to control the cost of micro lending in order to promote access to financial services. Interest rate ceiling can also help lenders in reducing their non-performing loan book (default rate) which has been a major problem. In general, interest rate ceiling has a significant relationship with the performance of micro lending market in Kenya. The direction and magnitude of the relationship depends on the specific aspect of the market.

\subsection{Recommendation}

In view of the findings and conclusions of the study, the following recommendations are of particular importance to the banking industry in Kenya. The effect of ceiling was significant among the variables under consideration; Credit supply, cost of credit and default rate. As established in the literature review, the intent of ceiling imposed by the government was to enhance financial inclusion by bringing down high interest rates, and since the findings show adverse effects on credit supply which is the base to financial inclusion, it is imperative that MFIs diversify 
their products that are geared towards accommodating the micro lending industry so as to remain competitive and to avoid losing customers to other competitors. In addition, the MFIs should balance their drive to make profits with a desire to serve micro enterprises by coming up with ways of reducing administrative costs and increasing credit supply. Perhaps the implementation of online lending through mobile phones can suffice if the Kenya government doesn't deregulate interest rates in the near future or has no intention of rescinding the cap rates.

\section{Acknowledgments}

We acknowledge Maseno University School of Graduate Studies and Tom Mboya University College, School of Business and Economics for creating conducive learning environment that made this work possible. We also acknowledge members of the School of Business and Economics of Maseno University for their constructive criticisms that also helped in improving the rigour of this work.

\section{References}

AIB Capital. (2016). Kenya's banking sector report. Retrieved on April, 2017 from http://www.aibcapital.com/

Almeida, H., Campello, M., \& Liu, C. H. (2006). The financial accelerator: Evidence from international housing markets. School of Hospitality Administration, Cornell University. https://doi.org/10.1007/s10679-006-9004-9

Avevor, E. E. (2016). Challenges faced by SMEs when accessing funds from financial institutions in Ghana. Published Thesis, VaasanAmmattikorkeakoulu University of applied sciences. Retrieved from https://www.theseus. $f i$

Bekaert, G., Harvey, C. R., \& Lundblad, C. (2005). Does Financial Liberalization Spur Growth? Journal of Financial Economics, 77, 3-55. https://doi.org/10.1016/j.jfineco.2004.05.007

Bernanke, B., Gertler, M., \& Gilchrist, S. (1996). The Financial Accelerator and the Flight to Quality. The Review of Economics and Statistics, 78(1), 1-15. https://doi.org/10.2307/2109844

Central Bank of Kenya-CBK. (2016). Bank Supervision Annual Report. Retrieved on April 17, 2018 from https://www.centralbank.go.ke/index.php/bank-supervision-reports

Chari, V. V., Shourideh, A., \& Jones, A. Z. (2010). Adverse Selection, Reputation and Sudden Collapses in Secondary Loan Markets. NBER Working Paper No. 16080. https://doi.org/10.3386/w16080

Childers, C. (2015). Micro lending in the Third World, Does It Work? Published Thesis, Liberty University.

Coric, B. (2011). The financial accelerator effect: Concept and Challenges. Financial Theory and Practice, 35(2), 171-196

Dankwa, I. O., \& Badu, G. P. (2013). Principles and practice of lending in the banking sector: A case study of some selected banks in Ghana. Journal of Contemporary Integrative Ideas, 1(2), 9-21.

Demetriades, P. O., \& Luintel, K. (2001). Financial Restraints in the South Korean Miracle. Journal of Development Economics, 64(2), 459-79. https://doi.org/10.1016/S0304-3878(00)00146-2

Djankova, S., McLiesha, C., \& Shleifer, A. (2007). Private credit in 129 countries. Journal of Financial Economics, 84, 299-329. https://doi.org/10.1016/j.jfineco.2006.03.004

Fernández, R. A. (2011). Financial liberalisation, asymmetric information and inflation: a new perspective on the Argentine financial experiment of 1977-81. PhD thesis, The London School of Economics and Political Science (LSE).

Fry, M. J. (1997). In Favour of Financial Liberalism. The Economic Journal, 107, 754-770. https://doi.org/10.1111/j.1468-0297.1997.tb00041.x

Heng, D. (2015). Impact of the New Financial Services Law in Bolivia on Financial Stability and Inclusion. International Monetary Fund, IMF working paper WP/15/267. https://doi.org/10.5089/9781513598420.001

Kariuki, M. W., \& Ngahu, S. (2016). Effect of interest rates on loan performance of micro finance institutions in Naivasha sub county Kenya. International Journal of Economics, Commerce and Management, 4(4), 549.

Khandare, D. M., \& Alshebami, A. S. (2015). The Impact of Interest Rate Ceilings on Microfinance Industry. International Journal of Social Work, 2(2), 10-17. https://doi.org/10.5296/ijsw.v2i2.7953

Kothari, C. R. (2004). Research Methodology: Methods and Techniques (2nd ed.). New Delhi: New Age International Publishers.

Kurlat, P. (2010). Lemons, Market Shutdowns and Learning. Working Paper, Stanford University. 
Laeven, L. (2003). Does Financial Liberalization Reduce Financing Constrains? Financial Management Association, 31(4), 5-34. https://doi.org/10.2307/3666202

Magali, J. J. (2013). Impact of Rural Savings and Credits Cooperative Societies (Sacco's) Loans on Borrowers in Tanzania. International Journal of Management Sciences and Business Research, 2(12), 17.

Maimbo, S. M., \& Gallegos, C. A. H. (2014). Interest Rate Caps around the World Still Popular, but a Blunt Instrument. Policy Research Working Paper 7070. World Bank Group. https://doi.org/10.1596/1813-9450-7070

Mbengue, D. M. (2013). The Worrying trend of Interest rates in Africa. CGAP. Retrieved on April, 2017 from http://www.cgap.org/blog/worrying-trend interest-rate-ceilings-africa

McKinnon, R. (1973). Money and Capital in Economic Development. Washington: Brookings Institution Press.

Miller, H. (2013). Interest Rate Caps and Their Impact on Financial Inclusion. Economic and Private Sector, Professional Evidence and Applied Knowledge Services.

Mohane, H., Gerhard, C., \& William, G. (2002). The Effects of the Interest Rate Ceilings on the Micro Lending Market in South Africa. Department of Agricultural Economics, Extension and Rural Development, University of Pretoria, Working paper: 2002-02.

Olaka, H. (2017). The Capping Interest Rates Debate: Market Failure or Necessary Intervention? Presentation at the 25th ICPAK Economic Symposium.

Orji, A., Ogbuabor, J. E., \& Onyinye, I. A. O. (2015). Financial Liberalization and Economic Growth in Nigeria: An Empirical Evidence. International Journal of Economics and Financial Issues, 5(3), 663-672.

Reille, X., \& Helms, B., (2004). Interest Rate Ceilings and Microfinance: The Story So Far. CGAP Occasional Paper 9, Consultative Group to Assist the Poor, Washington, DC.

Rossouw, Z. (2008). The impact of the national credit act on micro lending sales in a bank in South Africa. Gordon Institute of Business Science. University of Pretoria.

Shaw, E. S. (1973). Financial Deepening in Economic Development. New York: Oxford University Press.

Staten, M. (2008). The Impact of Credit Price and Term Regulations on Credit Supply. Joint Center for Housing Studies, Harvard University. UCC08-8.

Thomas, L. C., Edelman, D. B., \& Crook, L. N. (2002). Credit Scoring and Its Applications. Philadelphia: Society for Industrial and Applied Mathematics. https://doi.org/10.1137/1.9780898718317

Yunus, M., \& Jolis, A. (1999). Banker to the poor: Micro-lending and the battle against world poverty. New York: Public Affairs.

\section{Copyrights}

Copyright for this article is retained by the author(s), with first publication rights granted to the journal.

This is an open-access article distributed under the terms and conditions of the Creative Commons Attribution license (http://creativecommons.org/licenses/by/4.0/). 